\title{
Camp Lwandle: Rehabilitating a migrant labour hostel at the seaside
}

Noëleen Murray and Leslie Witz

\begin{abstract}
:
In southern African narratives of migrant labour, hostels and compounds are represented as typical examples of colonial and apartheid planning. Visual and spatial comparisons are consistently made between the regulatory power of hostels and those of concentration camps. Several of these sites of violence and repression are today being reconfigured as sites of conscience, their artefactual presence on the landscape being constructed as places of remembrance. In this trajectory, a space of seeming anonymity in Lwandle, some $40 \mathrm{~km}$ outside of Cape Town, was identified by the newly established museum, at the beginning of the twenty-first century, as a structure of significance. The migrant labour compound in Lwandle, of which Hostel 33 is the last remnant, was designed by planners and engineers and laid out as part of a labour camp for male migrant workers in the 1950s. This article explores the ambitious project initiated in 2008, by the Lwandle Migrant Labour Museum (and funded largely by the US Ambassadors Cultural Restoration Fund), to restore Hostel 33. Although Hostel 33 was not a very old structure, having been built in 1958/9, nor was it easily considered to have conventional architectural significance, its material presence in present-day Lwandle represents a reminder of the conditions of life in the labour camp. The article traces the work entailed in the restoration process through paying attention to both the built fabric and its materiality, and by giving an account of the explorations into finding ways to restore the hostel to the museum through making it into a site of significance. In place of the centrality of the building as the object of restoration, the work shifted to considering how the hostel could function most effectively as a stage and destination for the Museum's narrations of the past. Retaining and maintaining Hostel 33 was less concerned with the fabric as an empirical fact of the past, than with its projection into an envisaged future for museum purposes.
\end{abstract}

In the memorialisation of post anti-apartheid pasts, the camp has often been evoked as a symbol of suffering and of the possibilities of resistance. Several of these campsites are today being reconfigured as locations of memory. In a narrative of apartheid and resistance, the camp has materialised on the post-1994 memorial landscape as the site of apartheid's death squads (Fullard and Rousseau 2009), the places of incarceration and execution $^{1}$ and the space of the day-to-day repression of the figure of the male worker in the labour compound. While the first two were sites of extreme brutality, it was especially the compound and migrant labour hostel that was envisaged as the site of the 
ordinariness of oppression and as typical examples of control through colonial and apartheid planning. They were represented by the architect Julian Cooke $(2007,64,68)$ as "the core locus of perhaps the most destructive social engineering of the country's history, the migrant labour system," and could "show starkly how colonial and apartheid regimes used the spatial devices of jails or concentration camps to keep labour present and subservient, and in tandem with social regulation created a divided and violent land." Contained, enclosed, administered, surveyed, modularised and militarised, the labour compound of the migrant worker was reconceived as apartheid's camp (Mabin 1992b; Martinson and Leger 1992).

In these narratives of migrant labour, where hostels and compounds are described as settings where the experience of the regulatory power of apartheid's spatial configurations were most intense, a space of seeming anonymity in Lwandle, some $40 \mathrm{~km}$ outside of Cape Town, was identified by a newly established museum, at the beginning of the twenty-first century, as a structure of significance. Officially opened in May 2000 by the poet and former Lwandle resident Sandile Dikeni, the museum proclaims on its website (www.lwandle.com) that it serves as a reminder of "the system of migrant labour, single sex hostels and the control of black workers through the identity document which controlled the lives of black South Africans under apartheid - the infamous pass book." Lwandle was designed by town planners and engineers and laid out as part of a labour camp for male migrant workers in the late 1950s. In keeping with the housing compound typology that had emerged in the lexicon of apartheid space-making, Lwandle, sandwiched between the Helderberg mountain range and the seaside, was built to be purely functional, consisting entirely of hostel blocks. As the hostels were being reconfigured and refurbished into homes for family accommodation in the 1990s, the steering committee for the establishment of the Lwandle Migrant Labour Museum, consisting of the local librarian, Charmian Plummer, a resident of nearby Somerset West who was involved in setting up crèches in Lwandle, and Bongani Mgijima, a University of the Western Cape history student and Lwandle resident, decided to preserve one dormitory, block 6, hostel 33, as the physical remnant that would fix "the structure of things then" (Goldblatt 1998; Mgijima 2010). ${ }^{2}$ To be assigned the status of a building with significance, hostel 33, as a form of apartheid housing, needed much work. The hostel was not very old, having been built in 1958/9. There appeared to be no national or local narratives that singled it out as a site where specific events happened, where people of some import lived and/or as a last remaining example of the hostel typology of building beyond Lwandle. Even within Lwandle, it had no specific meaning. It was simply one among the anonymously numbered hostel structures.

Yet the building, which the museum wanted to hold onto as its primary artefact, was showing alarming signs of rapid deterioration. The windows were broken, warped and rusted, the roof had sagged from years of overloading in its interior, cracks were appearing in the wall and the very structure was vulnerable to the unrelenting winter rain. In 2008 the Lwandle Migrant Labour Museum began an ambitious project, primarily funded by the United States Ambassador's Cultural Restoration Fund, to restore the hostel. 3 This article concerns itself with this project and seeks to show that the work entailed both paying attention to the built fabric and its materiality and finding ways to restore the hostel to the museum through making it into a site of significance. The choice 
of the word fabric in this instance is a term mobilised to make reference to the materiality of the building as it is used in technical jargon in the process of building construction, in the sense of "built fabric."

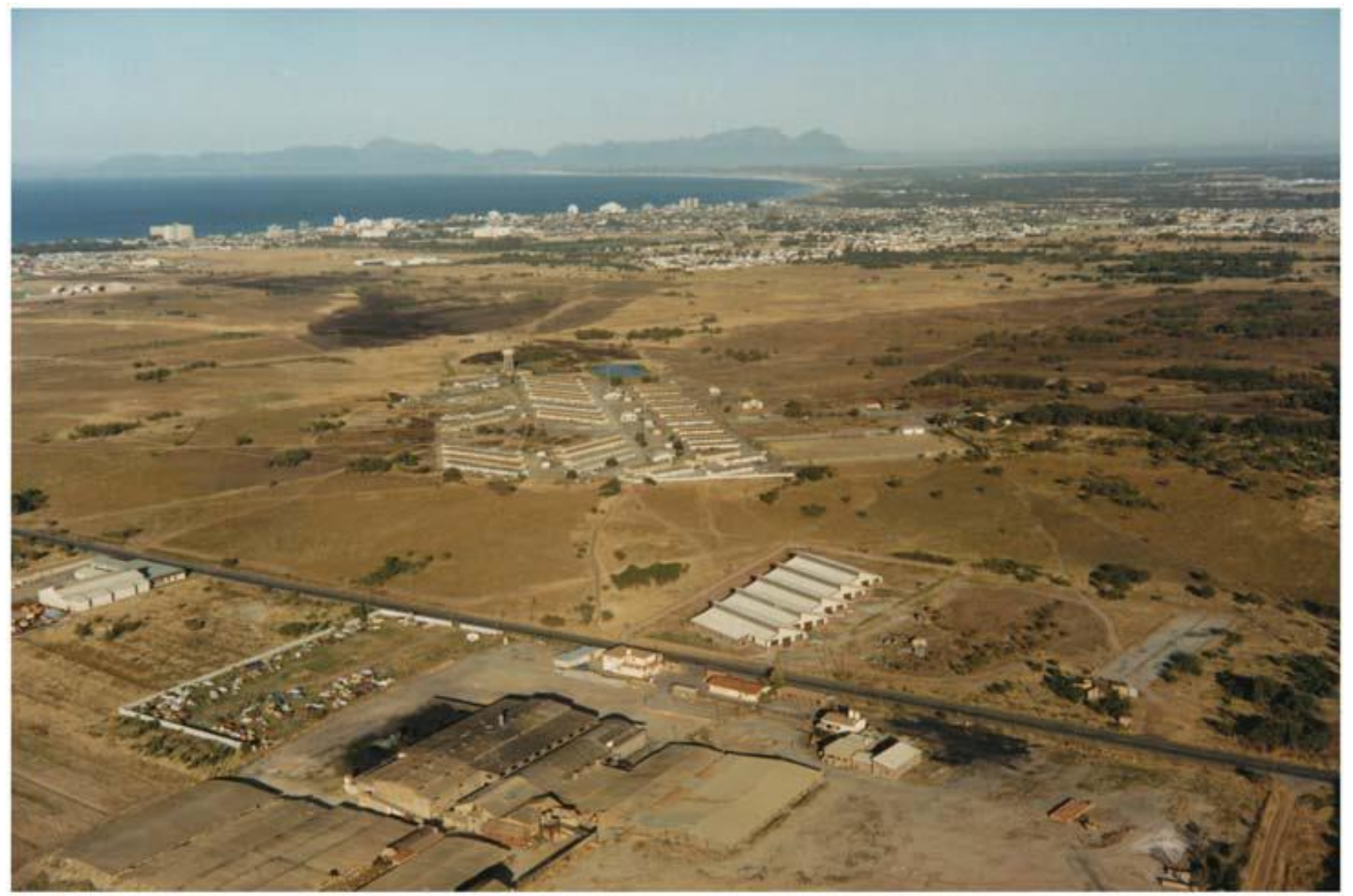

Figure 1. Lwandle hostel compound, 1987. Aerial photography formed part of an investigation carried out on behalf of the Urban Foundation into the possible scenarios for Lwandle's future. Copyright, Andrew Berman Urban Design Services.

But it is also intended to place the hostel in a tension between the industrial notion of "fabrication" (and by extension replication, standardisation and machinemade) and the flimsiness of the actual fabrics used by those who modified and personalized the interior spaces through the use of hessian for ceilings, remnants of cloth for curtain dividers and an assortment of wooden planks as room partitions. The hostel had been fabricated as much by its bricks and mortar as by its inhabitants.

The article draws extensively upon our own experience and involvement as members of the Board of the Lwandle Migrant Labour Museum in the restoration project of Hostel 33. As a historian and an architect, we became intensely involved in a set of hands-on collaborations with museum staff, residents and the appointed professionals during the restoration process as we constantly negotiated design decisions and approaches to the project. Drawing upon our deep involvement in the project, we argue that the movement of hostel 33 to the museum was a process of rehabilitating and reinhabiting the site. What rehabilitation, rather than restoration, meant was not trying to locate and fix an originary moment but trying to depict layers of meaning and adaptation over time. In place of the centrality of the building as object, the work shifted to how the hostel could function most effectively as a stage, prop and destination for the Lwandle Migrant Labour Museum's narrations of the past. In this way, the process of restoring Hostel 33 challenged the limits 
of conservation architecture. Retaining and maintaining Hostel 33, as set out by the museum, was less concerned with the building as an empirical fact of the past than with its projection into an envisaged future for the museum. 4

\section{Planning camp Lwandle}

ELwandle ("at the sea" in isiXhosa) was first envisaged in the mid-1950s by the National Party government, which had come to power several years earlier with a promise to implement apartheid. Conceived initially as a "Location and Native Village" in the Helderberg region between the towns of Somerset West, Gordon's Bay and Strand, 5 the plan was to control the increasing number of workers from the Eastern Cape who were finding employment in the burgeoning fruit and canning industries in the region and the municipal services of the associated towns. Many of these workers, who were racially classified under apartheid as "native," and later as "bantu," had found accommodation in backyards of houses in Somerset West and Strand (Mgijima and Buthelezi 2006, 798). Under the Native Urban Areas Act of 1923, and subsequently amended in 1930 and 1945, these workers were cast as temporary migrants on short-term contracts (Jones 1993, 910; IJR and Lwandle Migrant Labour Museum 2008, 14-15). From the 1950s, the Native Affairs Department sought to bring what it referred to as "rationality" to this labour system by asserting and maintaining a supply/demand model. It tightened up the regulations under the Native Laws Amendment Act (1952) and introduced local labour bureaus where jobseekers were required to register their intention to find work, and employers in cities were obliged to "register all vacancies for Africans." The intention was that each labour bureau would thus be able to create a correspondence between "the labour supply and demand, ensuring that job-seekers were placed in work ahead of migrants" (Posel 1989, 203-204).

Moreover, in the western Cape Province a policy was implemented that gave priority in the allocation of jobs to people who were designated as "white," then to people who were racially classified under the 1950 Population Registration Act as "coloured," and finally, when no other option was available, to those who were officially termed "native." The Eiselen line, "drawn around the western Cape," in 1955 declared the region "a Coloured Labour Preference Area" (Christopher 1994, 12). Workers designated as "natives" were considered "foreign" to the western Cape Province; and while they were required in several sectors, their presence was deemed to be provisional (Jones 1993, 11; IJR and Lwandle Migrant Labour Museum 2008, 17; Humphries 1989). Not regarded by officials as being at "home" in Strand and Somerset West, the workers were to be regulated through the provision of very basic, rudimentary hostel-type accommodation. As Buthelezi has pointed out, eLwandle was planned to become emaHolweni, the place of halls/hostels for amaGoduka, the migrant workers (Buthelezi 2005, 67).

But what concerned the planners of Lwandle was the paradox of its visual presence. On the one hand, hostels needed to be constantly surveyed and seen in order to maintain control over the movement and activities of its inhabitants. On the other hand, the hostels had to be invisible and not appear in the image of what the government referred to as a "black spot." The term "black spot" emerged as a reaction to the apartheid state's inability to manage populations who settled in contradiction with the strict rules of settlement nationally as influx-control regulations began to become unenforceable. With a South 
African future being defined through a citizenry constituted as white and a past derived from settlement (Witz 2003), necessary subjects within its imagined spatial boundaries could not be seen to appear on the landscape. Whether or not the term "black spot" was an intentional reference to race, it certainly connoted a "blot" on the landscape of whiteness imagined by apartheid's architects (Mabin 1992a). The regional Urban Areas Commissioner in the western Cape Province, C.J. van Schalkwyk, thus agreed with requests from industries to provide some sort of basic accommodation in hostels for migrant workers in the Helderberg region, but was deeply concerned that this would create a "black spot" in the area. What van Schalkwyk wanted was that the Stellenbosch Divisional Council would ensure that the provision of hostels would help "eliminate" these spots and that publicity around the construction would emphasise that this was the intention and not the converse, which some might assume to be the case. ${ }^{6}$ Lwandle could come into existence, and was punted by both the Department of Native Affairs and the Divisional Council of Stellenbosch for the next few years as a matter of extreme urgency, 7 but it had to be made as invisible as possible.

This was achieved through the government purchase of a farm alongside the national road leading to the north-east between Somerset West and the pass over the Hottentots Holland mountain range belonging to C.P.J. van Vuuren. Van Vuuren maintained that when he had initially bought the farm it was desolate, "kaal, soos natuur dit gelaat het" ("naked, like nature left it"); he had initiated substantial improvements by installing boreholes, building a farmhouse, planting fruit trees and putting up fences and windbreaks. Whether the farm was as desolate as van Vuuren described it is difficult to tell, as he was at the time negotiating the selling price with the Ministry of Native Affairs and the Stellenbosch Divisional Council. Van Vuuren's farm was imminently suitable for the construction of Lwandle. Not only was it in easy reach of the towns of Somerset West, Strand and, to a lesser extent, Gordon's Bay, but it was far enough to appear as a spatially distinct, separate, perhaps even rural, locality. The windswept harsh environment near to the sea also made it a marginal farming area. Van Vuuren's property had formed part of the larger farm, Gustrouw, which had been subdivided in the mid-nineteenth century into a series of smaller plots (Heap 1977, 60-66). It had been used in the eighteenth and nineteenth centuries largely for cattle farming; and although van Vuuren had attempted to grow fruit trees, when contrasted with the protected prime agricultural lands on the slopes of the nearby Helderberg range, this was a far from ideal farming environment. In spite of van Vuuren's efforts to inflate the price by appealing directly to the Minister of Native Affairs, Hendrik Verwoerd, 19 morgen of the farm Gustrouw was purchased by the Stellenbosch Divisional Council for £14,000 and Lwandle was established in terms of Government Notice no. 71 of $1958 .^{8}$

Making use of the underlying cadastral boundaries, 22 hostels for single men were to be built, an eating hall and kitchen established, a shower and laundry block constructed, land set aside for a communal hall, beer hall and sports field, and van Vuuren's farmhouse turned into a police station (which colloquially became known as the "Withuis" or White House). Surrounding Lwandle was to be a 250-yard "buffer zone" to the boundary with the National Road. This was in keeping with the mechanisms of segregation that formed key components of apartheid planning in South Africa, where devices such as buffer strips and industrial zones literally "buffered" designated racial 
groups and functional zones. The only access to Lwandle was along a small narrow strip, leading off from the National Road, where no other form of construction was permitted. 9

But while Lwandle was made to be remote, it was also controlled through features that made it highly visible. An aerial photograph on display in the Lwandle Museum, dated to 1977, shows how control was effected through the design and layout and the hostels. Designed in a linear manner, configured in parallel rows of double- and single-storey structures, the hostel blocks were laid out around a central core space in a chevron-type pattern, allowing for "clear lines of sight" along the rows. ${ }^{10}$ In each row, there were a number of units. Each unit had a single exit/ entrance, was divided into two rooms, and each of these further subdivided into four small, confined individual compartments containing two or four beds, with up to 32 men in a hostel block, their lives effectively reduced to a "bedhold" (Ramphele 1993, 22). Each hostel unit had an outside latrinal block with open cubicles that made use of the bucket system, and in close proximity were communal kitchens and showers. The visual paradox of the Lwandle hostels was that they were created to be unseen, as if they did not exist, yet were so eminently observable by compound managers and police that there was no way that any sense of privacy could be achieved.

Despite attempts at control, by the mid-1980s Lwandle was becoming more and more visible from the national road. A combination of limited apartheid reforms, which eased restrictions on urban residence, and increasing poverty in rural areas, had combined to increase the numbers of women and children who were coming to live in the hostels. Residents of Lwandle, particularly women, were subject to constant harassment and raids as police sought out those who did not have the necessary documentation required by apartheid legislation and regulations to live in the city (Sloth-Nielsen, Hanson, and Richardson 1992). The buffer zone was also beginning to dissolve. The large space of open ground provided the ideal opportunity for those living in Lwandle to create their own pathways that did not follow the singular access road. As Witz has described, an aerial photograph of Lwandle taken in the late 1980s shows that "the buffer zone had become criss-crossed with multiple self-made paths as those who lived in Lwandle sought out the most convenient and easiest ways to traverse the routes to places of employment, residence and the surrounding towns" (Witz 2011, 375). Local government and residents of the surrounding towns started coming up with new plans for Lwandle. Envisaged scenarios included providing family housing, building more hostels or simply eradicating what was now being depicted as an unsightly "black spot" from the landscape of the future (Urban Design Services 1987, 55-64). 


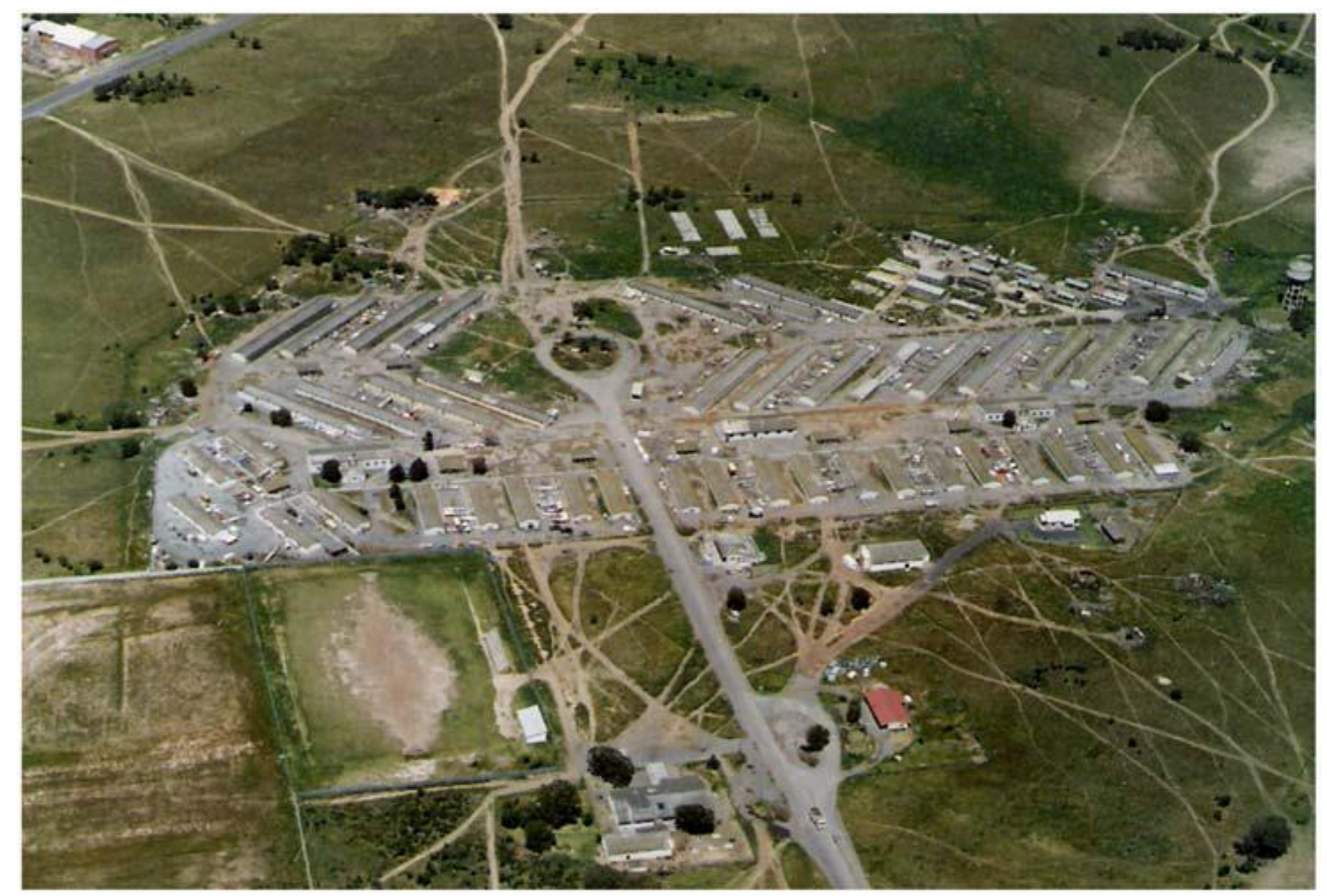

Figure 2. Aerial photograph of Lwandle 1977 on display at the museum. Photo: LMLM Collections.

Drawing an analogy with concentration camps, the local press increasingly reported on living conditions in Lwandle. On April 11, 1986, the Helderberg District Mail, a small local newspaper largely aimed at a suburban readership in Strand, Somerset West and Gordon's Bay, ran an article in which the mayor of Somerset West, Walter Stanford, described the "disgusting concentration camp type conditions in Lwandle."11 Effectively mobilising sets of evidence for the various proposals on the table for Lwandle's future, photographs were published revealing the bucket system, the cold showers and the confined space of the hostel interior. The photographs and writing referred to Lwandle as "our concentration camp," labelled those who lived there as "inmates," and called the area a "greenhouse for disease."12 A few months later, Franco Inches, the Chair of the Hottentots Holland Chamber of Commerce, again invoked the concentration camp metaphor and argued that Lwandle should not become a "Belsen."13

\section{De-camping Lwandle}

For many years there followed intense and often acrimonious negotiations over Lwandle's future. Many residents of Strand, the "extensive seaside resort, with specially set aside residential, dining, beach and recreational facilities for people who were racially classified as white under apartheid" called for its removal, while the local Hostel Dwellers Association, non-governmental organisations, and some industry representatives advocated for conversion to family housing (Witz 2011, 373; Urban Design Services 1987 , 66). In the early 1990s, as violent conflicts surfaced across the country between hostel residents and local township dwellers, the apartheid state was also beginning to succumb to a view that hostels would have to be significantly upgraded (Thurman 1997, 48). 
Lwandle was declared a township, rescued from its imminent demise and recast as one of the first sites of the Hostels to Homes projects that sought to unsettle the labour camp.

In 1993, when the local authorities embarked on remaking Lwandle from single male hostel accommodation into homes, a long consultative process began in which families were identified, homes were allocated and space was re-envisioned to transform the labour camp into spaces for families to live their lives in an envisaged post-apartheid city. In response to a request from the Hostel Dwellers Association, the Development Action Group, in association with ACG Architects and engineers Liebenberg and Stander, started the process of work on the project of transforming the camp from "open barracks" into private family accommodation. Consultants and residents sat poring over plans of the old compounds and began sketching new configurations for these new units; slowly, a new place began to emerge as internal arrangements were manipulated on plan. Doors, rooms, roads, pavements and solar water panels were added to open these units to new possibilities of making homes from the camp. The first homes were completed in 1998, altering the interior of the dormitory camp with new separate entrances, ceilings and hotwater showers, and toilets and basins shared between two family units. ${ }^{14}$ From the newly created and named streets, in amongst the roofscape of gleaming solar panels, homes were overlaid on the camp-like arrangement of the exterior of the barrack layout. As Vusi Buthelezi $(2005,67)$ pointed out, even though Lwandle no longer had "hall like structures for residents" and was "no more a place of "amaGoduka'," the term "emaHolweni" still remained in place "as an identity of Lwandle."

Yet the identity of "emaHolweni" was explicitly being countered through the physical reconstruction of Lwandle. Not only were the hostels being turned into homes, but schools were built, a library and new community hall were constructed, and the ruins of a burnt-out beer hall transformed into a centre for arts and crafts; this all signalled the development of new notions of a public in Lwandle based upon ideas of family, permanence and a responsive and responsible citizenry. It was in this moment of decamping that the executive of the Helderberg municipality decided in 1998 to support a proposal that "hostel no. 33 in Lwandle be retained for the purpose of the establishment of a museum." 15 This was the ultimate challenge to Lwandle as a transient space, typified by regularised dormitory accommodation. Even though there was little idea as to what the structure and contents of this place called a museum would entail, the very idea asserted the possibility of a settled public citizenry "with a recognizable and recoverable past called history" (Witz and Murray 2011, 13). 


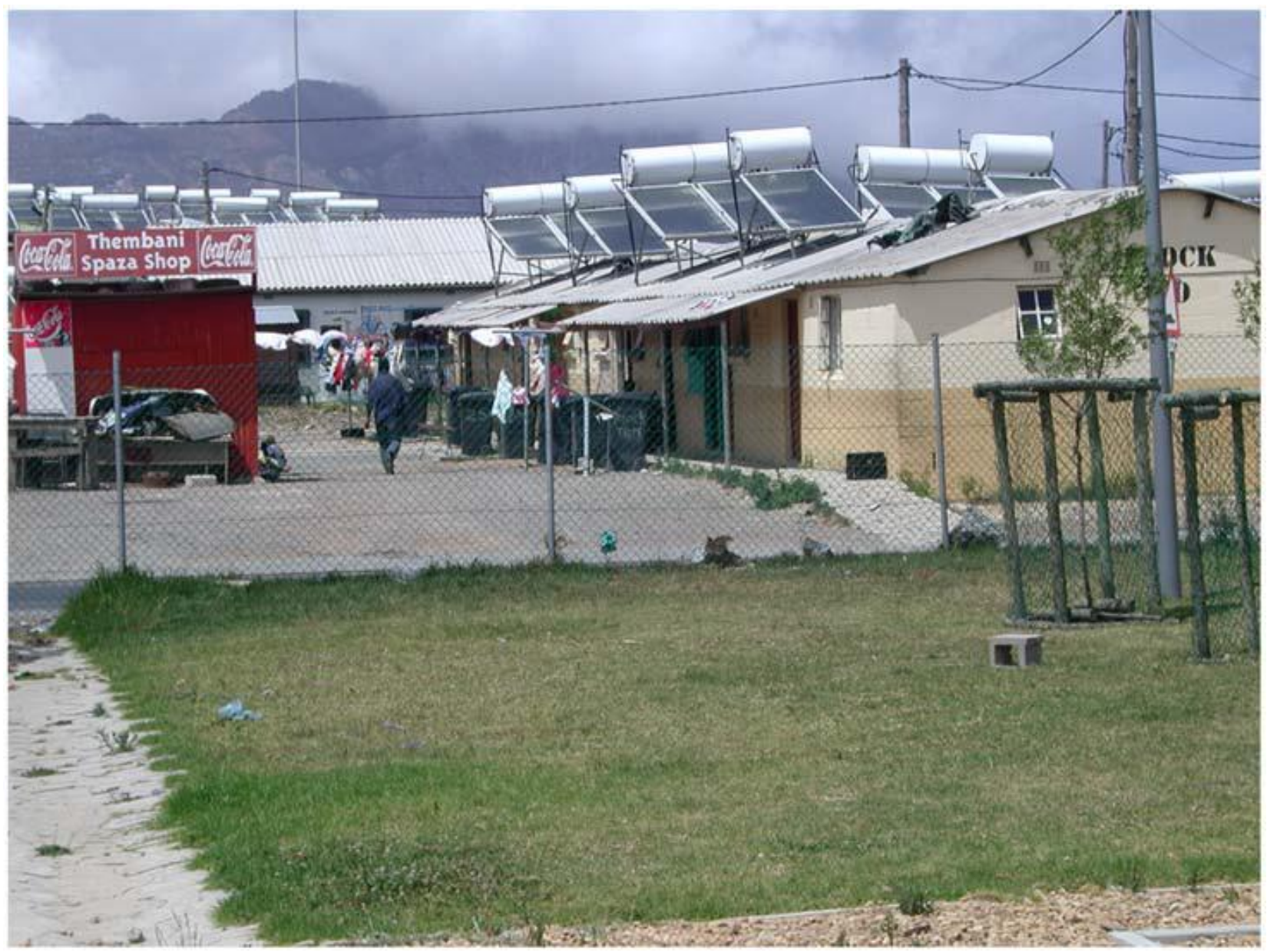

Figure 3. Lwandle hostels transformed into homes, 2007. A view of the museum's neighbours. Copyright, Leslie Witz.

What was being asserted was that an existing unreconstructed hostel block among the new homes that were taking shape would be the key signifier and artefactual presence of the envisaged museum. This was completely different from the ways that migrant labour hostels were being reconfigured in post-apartheid South Africa by architects, town planners and heritage practitioners. Sometimes they had been converted into family accommodation, as most were in the case of Lwandle, or torn down to make way for new housing developments (Cooke le Fèvre 2009). In other instances, they were either refurbished or used unaltered as dormitories mainly for male workers. Sometimes they were abandoned and left as almost hidden landscapes of the past, such as Zwelihle, the AECI Labour Compound adjacent to Somerset Mall in Somerset West. When they were made into museum pieces, they were either created as dioramas, such as at the KwaMuhle Museum in Durban and Museum Africa in Johannesburg, or completely restored and cleaned up to become museums of themselves, such as the Workers' Museum at the Newtown cultural precinct in Johannesburg. In contrast, in Lwandle, the idea was that the old hostel block would remain on the reconstructed landscape so as to remember a past, becoming what Paul Williams refers to as a "memorial museum" of the present. This type of museum is explicitly political, providing historical interpretations within a "moral framework" and their defining characteristic is that they "function as a memorial" (Williams 2007, 8). The contradiction in the case of Lwandle was that while it was being decamped, the notion of the museum being set in place was to maintain and recreate a part of the camp as the sign of settlement. 


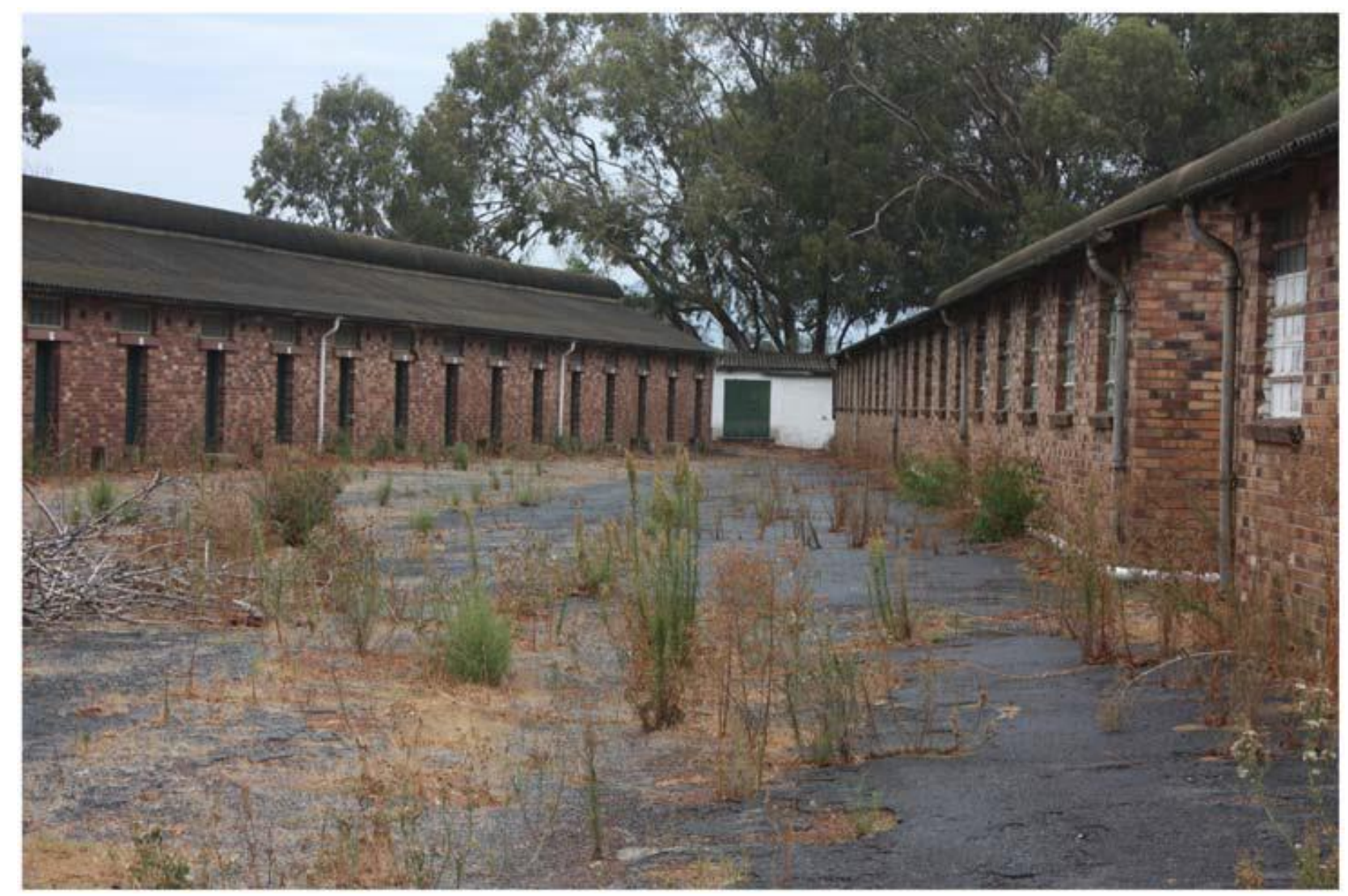

Figure 4. Zwelihle, AECI Labour Compound, Somerset West, 2011. Museum Board members were invited by heritage consultant Melanie Attwell to view and comment on the heritage significance of the site. Copyright, Leslie Witz.

Creating the museum of the camp as a sign of change meant that hostel 33 was an awkward, difficult marker for a history of the labour camp. Still inhabited by a number of different and successive occupants who could not find accommodation in amongst the new and refurbished facilities, it increasingly deteriorated, intensifying its dehumanising form. The museum established itself rather in the recently vacated old community hall; and, while it took visitors on walking tours of Lwandle that included hostel 33 as its prime destination, it also had to continually negotiate with residents and authorities to find alternative accommodation (Mgijima, 2010). It was only in 2007, when the last residents of hostel 33 moved out into new houses, that the space eventually was ready to be remade into the already existing museum as a memory of the camp's past.

\section{Rehabilitating the camp}

The contradictory process of unmaking and remaking the camp into a site as part of a new Lwandle and its museum entailed embarking on a restoration project that was unlike most others previously completed. After all, the hostel building did not fit into any historical categories of "Architecture of the Cape," which is recognizable through its characteristic heritage of "high style and vernacular" forms (Rapoport 1992; Fransen and Cook 1980; Shepherd and Murray 2007, 2-3). All the hostel compounds in Lwandle were designed in monotonous regularity and constructed using building materials of the lowest specifications: barrack-like structures with cheap stock bricks (walls were built without cavities), ungalvanised steel windows, low-pitched corrugated iron roofing and no ceilings. The challenge of the restoration process, which effectively began in 2009, was how to ensure that the camp in all its ugliness and instability remained while at the same 
time securing it as a visual marker of a past that the museum wanted to set in place. There was the associated issue of how to represent a history through a building that was initially conceived as the structural unit of the male dormitory hostel, but which had, over time, taken on other uses and many other inhabitants. Would it be a display of conditions in the 1960s, when the hostels were started and only intended for male migrant workers? This would assist the museum in depicting how, in its starkest and most brutal terms, the migrant labour system was operationalised. Or would it be more effective to depict the 1970 s and 1980s, when many women lived in the hostels, defying the regulations and often being arrested? Or would the period since the 1990 s be another option, when those who had not been allocated new housing had found what they hoped was temporary accommodation in the hostel?

In all these explorations, it was clear that both the fabric of the building and the multiple and contested histories indicated the complexity of attempting to secure a past through restoration. Although up until now we have talked about a project of restoring the sign of the camp through the individual hostel, what rather came into play can instead be better termed as rehabilitation. Here, the idea was that the hostel had a biography that needed to be configured into the ways the project was carried out. That the hostel had a biography referred to the various uses and inhabitation of the structure through different periods. But while biographic moments could be represented as many, diverse and constantly changing, the physical structure of the building had to be made secure for the museum. The philosophy of rehabilitation conveyed by the Standards for the Treatment of Historic Properties in the United States, and followed by the architects involved in the restoration of 97 Orchard Street for the Lower East Side Tenement Museum in New York City, provided the Lwandle Museum with such a direction: "the act or process of making possible a compatible use for a property through repair, alterations, and additions while preserving those portions or features which convey its historical, cultural, and architectural values" (Li/Saltzman 2002, 2). The aim was not to create an illusion of authenticity, but to intervene as little as possible in the existing structure, make repairs where necessary and make it completely apparent where there had been recent interventions. "Stabilization, restoration, and public access" (Dolkart 2007, 119) were the key principles proposed, so that the almost anonymous, ordinary example of hostel dormitories at hostel 33 could be made into Hostel 33 for “museum purposes.”16

Ideas to begin the remaking of hostel 33 by chance coincided with a recrafting of United States cultural policy into what Christina Luke has referred to as "cultural diplomacy." She maintains that the preservation of monuments and objects was "an effort to communicate a softer image abroad" by the US Department of State. Compared with military spending, she argues, such an approach was "inexpensive" and had the "potential to be extremely positive, especially if recognition of an historic structure garners political prestige and fosters economic opportunities, most often through tourism" (Luke 2011, 3). What cultural preservation offered was:

an opportunity to show a different American face to other countries, one that is noncommercial, non-political, and non-military. By taking a leading role in efforts to 
preserve cultural heritage, we show our respect for other cultures by protecting their traditions. (US Department of State 2004)

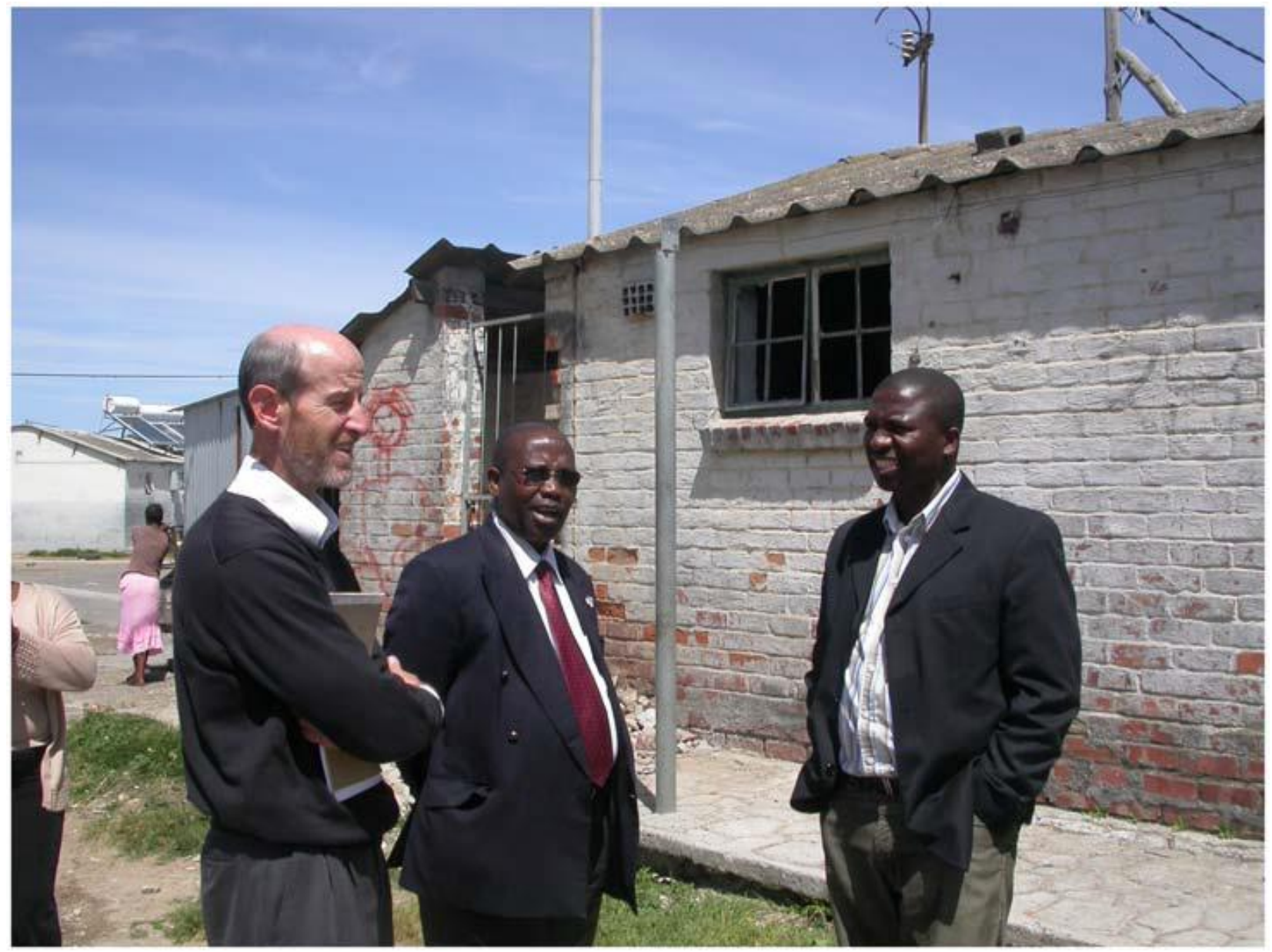

Figure 5. Hostel 33 on-site inspection. On October 23, 2008 Mark Canning (left) from the US Consulate in Cape Town visited Lwandle Museum along with Sisa Ngondo (right) and other representatives from the City of Cape Town who have supported the Lwandle Museum in numerous ways. Copyright, Noëleen Murray.

This policy materialised in the establishment of the US Ambassador's Fund for Cultural Preservation, which sought to support "a wide range of projects to preserve cultural heritage, such as the restoration of historic buildings, assessment and conservation of museum collections, archaeological site preservation, documentation of vanishing traditional craft techniques" as an indicator of "the depth of [...] respect for the cultural heritage of other countries" (US Department of State, Bureau of Education and Cultural Affairs 2012). Mark Canning, the public diplomacy officer at the US Consulate in Cape Town, encouraged the museum to apply for this competitive international award around a project to restore Hostel 33. Although neither a monumental project nor a treasured antiquity, Hostel 33 appeared to fit the categories of situation, marginality and the potential for generating local economic development. The museum's application was successful: in 2009, Hostel 33 was listed in the US Ambassador's Fund for Cultural Preservation Awards as a project that is given the inflection of the camp: "Restoration of a mid-2oth century Hostel at the Lwandle Migrant Labour Camp Museum" (US Department of State, Bureau of Educational and Cultural Affairs, Cultural Heritage Center 2009). 
Repositioning the camp through its conservation and curation to make it into a museum demanded finding a way to keep its alienation in place. Even though in 1998 the idea was that hostel 33 should be kept intact as a museum structure in amongst the transformed homes, what had happened was that the building had in part been assimilated into the new urban landscape. When hostel 33 was designated to the museum, the development in and around its immediate surroundings had ceased. What was left in 2009 was a trace of the arrested process visible in the remains of a planned covered stoep: steel poles, a concrete apron, a grass verge, a communal washing tub and drying lines. Moreover, hostel 33 had changed shape, as it was opportunistically appropriated by neighbours for their own purposes. Brick by brick, the screen wall at the entrance to the disused toilet section was dismantled; a lean-to carport was affixed to the back wall; a storage bungalo for a nearby convenience store encroached on the site adjacent to the end wall of the bucket system area; and a dumpsite flourished in the old latrines.

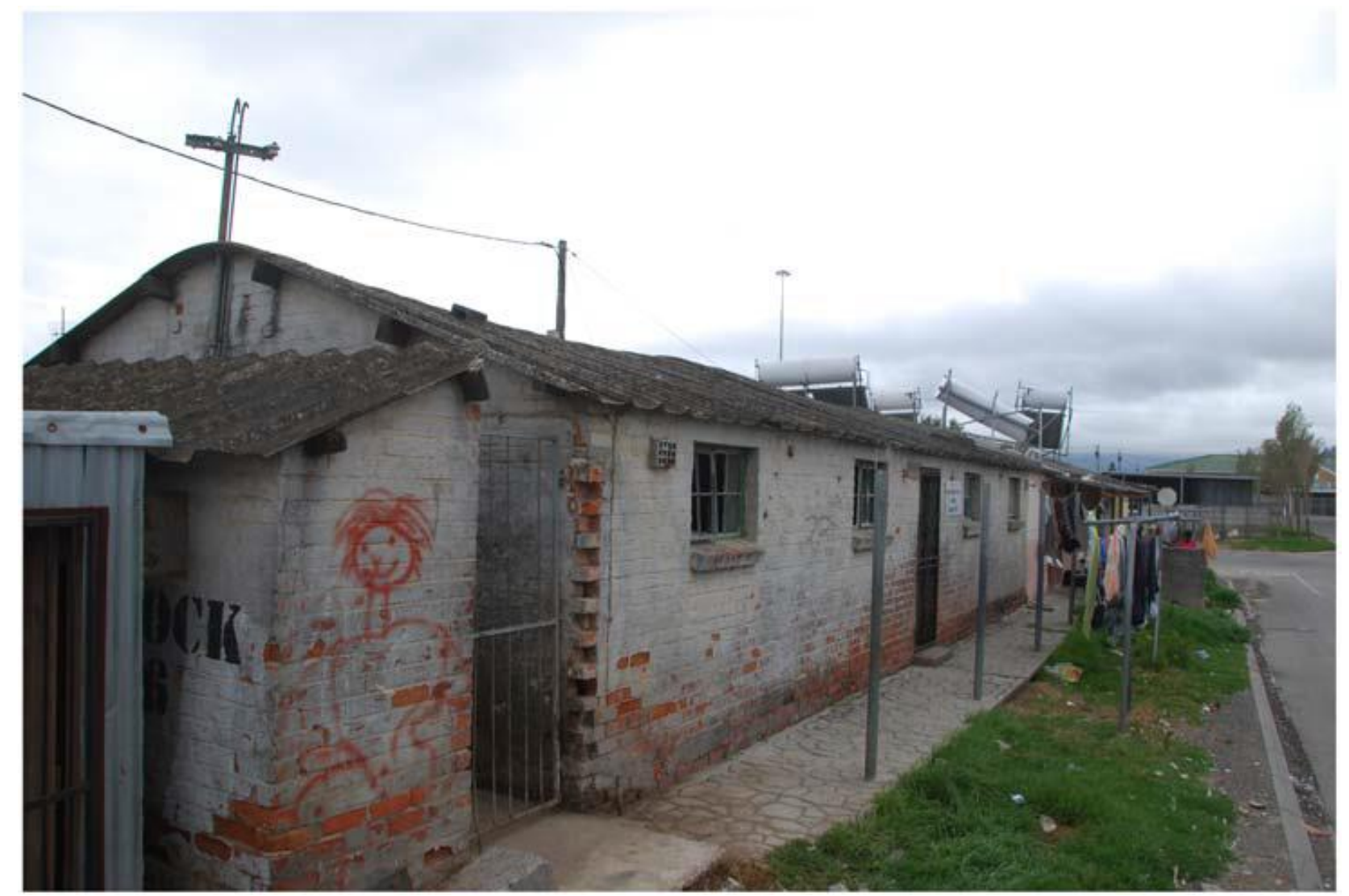

Figure 6. Hostel site before restoration commenced, March 2009. Experienced building contractor, Jerry Rogers, conservation architect William Martinson and industrial archaeologist David Worth visited hostel 33 and gave advice on how to proceed with the restoration of the decaying fabric of the low-spec building. Copyright, William Martinson.

These were obviously additional layers of the building's biography; but at the same time, they obscured a narrative of the camp that the museum was producing. That narrative was one that emphasised the experience of migrant labour and wanted the hostel to be primarily an artefact that could enable this telling. The additions since 1998 interrupted this discourse of labour. Museum staff, members of the management board and the professional team that had been appointed to restore the hostel, including Jakupa Architects and project manager Renchius van der Merwe, decided to set the building apart as old. Making use of a photograph in the museum's archives from the mid-1980s as 
a key source, the local contractor, Laings Koti, rebuilt the latrine screen wall, destroyed the paved apron to make way for a gravel surround, took away the carport and storage bungalo and removed the washing lines. In some ways, this departed from the ideas of minimal intervention and rehabilitation through the displacement of the more recent additions and alterations to make way for the story of containment, regulation and estrangement. It was the museum's image of the camp that was being set in place.

That image found its ultimate expression in the re-creation of the bucket system toilet block, where the intention of the museum was to depict the rudimentary sanitary provisions, the lack of privacy, and the rawness of the bare timber seats and crumbling walls of the open cubicles. Since the Hostels to Homes project had been completed, waterborne sewerage had replaced the bucket-soil system in Lwandle and the structure adjacent to hostel 33 was the only remaining trace of this prior way of managing effluent. Indeed, according to Bongani Mgijima and Vusi Buthelezi (2006, 799), this was why hostel 33 was initially selected in 1998 as the foundation of the museum.

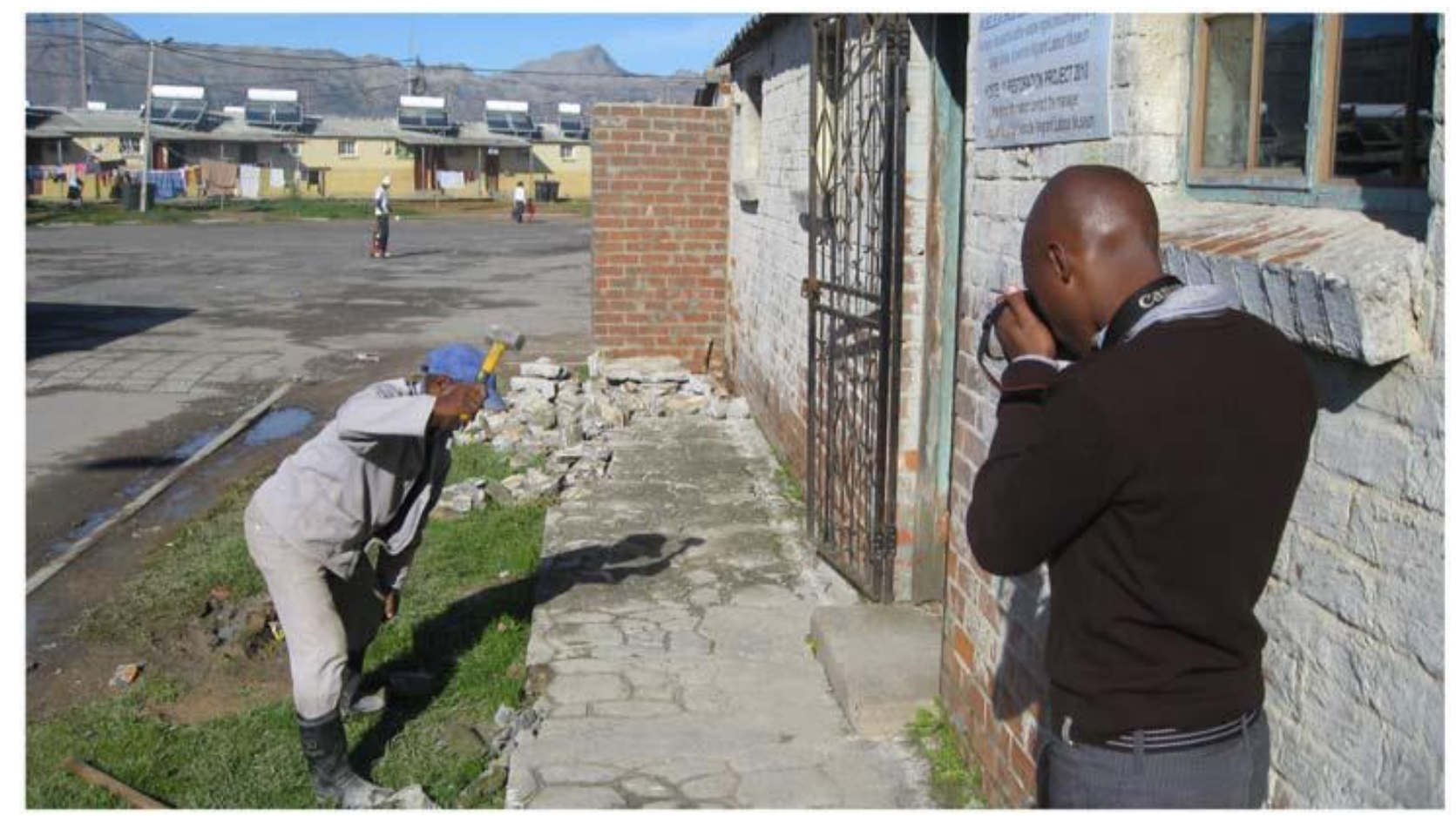

Figure 7. Hostel 33 additions dismantled. Museum staff member Phumzi Nzuzo documents the removal of the concrete apron, June 2010. Copyright, Noëleen Murray.

The rehabilitation project, of course, could not even attempt to re-create the bucket system in its entirety. Showing the unhygienic conditions was not realistic. Images contained in a report conducted by the Urban Foundation in the late 1980s, Sean Jones's ethnography of youth and family life in Lwandle, accounts from women and men who had lived under this system, and from chemical engineers involved in the decommissioning of bucket toilets across the Western Cape provided clues for exhibitionary representation. The museum manager, Lunga Smile and an intern, Nqabakazi Ntoni, oversaw the emptying of the rubble from the latrine area that accumulated there through illegal dumping; the crumbling brick walls of the cubicles were rebuilt by the contractor, Koti; plastic buckets were sourced from nearby Theewaterskloof Municipality, with the assistance of the municipal official Denver Damons; and steel urine buckets were 
purchased from junk shops by designer Jos Thorne. Wooden toilet seats were remade by a film-set builder, Dave van Wyk, to specifications determined by measuring dimensions between remnants of the steel angle supports and a fragment of one deal timber seat found on site and by inspecting a photograph from the Urban Foundation Report that showed the shape of the seat (Urban Design Services 1987; Jones 1993; Murray 2010). In five of the cubicles, toilet conditions were represented; the sixth was left undisturbed, with only the remnant of the rusting steel supports as a shard of the recent.

The making of the hostel into a museum among the homes of Lwandle entailed setting it apart, yet it could not do the same to the community it was asserting as its primary public. An indication of the ability to include open public participation was one of the key reasons why the museum appointed Jakupa Architects to the project. This took the form of what they described to museum staff and board members as a "charette," where ideas from various stakeholders could be explored in workshops to develop a project brief. Lunga Smile gathered together neighbours of hostel 33, who articulated their visions for the future of the dilapidated structure graphically on small cards that were then affixed to the wall for debate. Security was singled out as a major concern that the design should address. Although the ideas of ring-fencing the site that were proposed were ultimately spatially complicated, security glass-plated windows were installed, branded burglar bars were built into the masonry on the back facade and galvanised gates secured the two doors. But overall, this process - which promised openness, accountability and a "shared authority" - was difficult to sustain as the condition of the building was assessed, plans were drafted, and experts were consulted in the fields of project management, structural engineering, industrial archaeology and conservation architecture (Frisch 1990; Murray 2010). Instead, as the project developed, on-site negotiations took place between the contactors and affected surrounding residents. An agreement was reached with the owners of the temporary carport that a new free-standing structure would replace it, washing-line wires were given to immediate neighbours in the street to fill in where theirs had gone missing, old window clips needed for the restoration were traded for new ones, and after some lengthy negotiations with Lunga Smile, the owner of the bungalo was paid out a substantial amount to clear the area around the end wall of hostel 33. Buying into the process, as it turned out, was less about community than hard bargaining.

The second phase of the project shifted to the interior spaces of the hostel. Inside, the evidence of sustained usage over 40 years since construction was immense. Wooden partitions filled in the open space between compartments and the corridor, sacking provided ceiling insulation, walls were painted and sometimes papered with industrial off-cuts and photographs from magazines were used for decoration. Inside this layered interior, the curatorial issues of periodisation and extent of possible removal were accentuated. Not only was this an intellectual exercise of layering history, but it was also a technical question of what might occur if parts of the whole began to be dismantled. Everything was interconnected. In this delicate web of personal modifications to an original space with its hostile uniformity, the appearance of these improvised structures provided the "stories of home," resonating with the museum's main exhibition in the nearby Old Community Hall. ${ }^{17}$ The question of re-inhabitation of Hostel 33 for the museum was about how to imagine different scenarios of hostel homes without residents. 


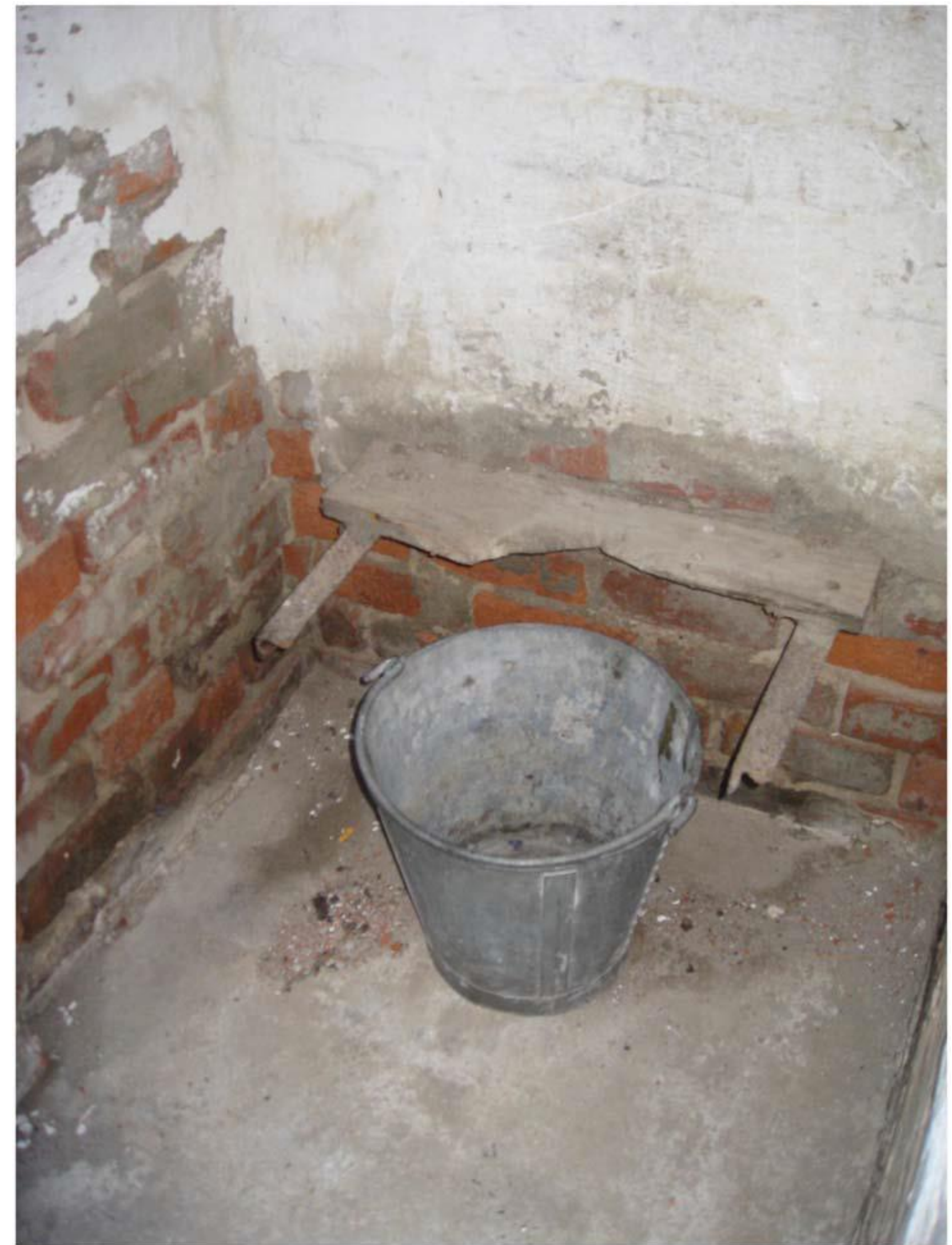

Figure 8. Archaeological shards. Remnants of the bucket toilets on site provided clues for restoration, May 2010. Copyright, Noëleen Murray. 


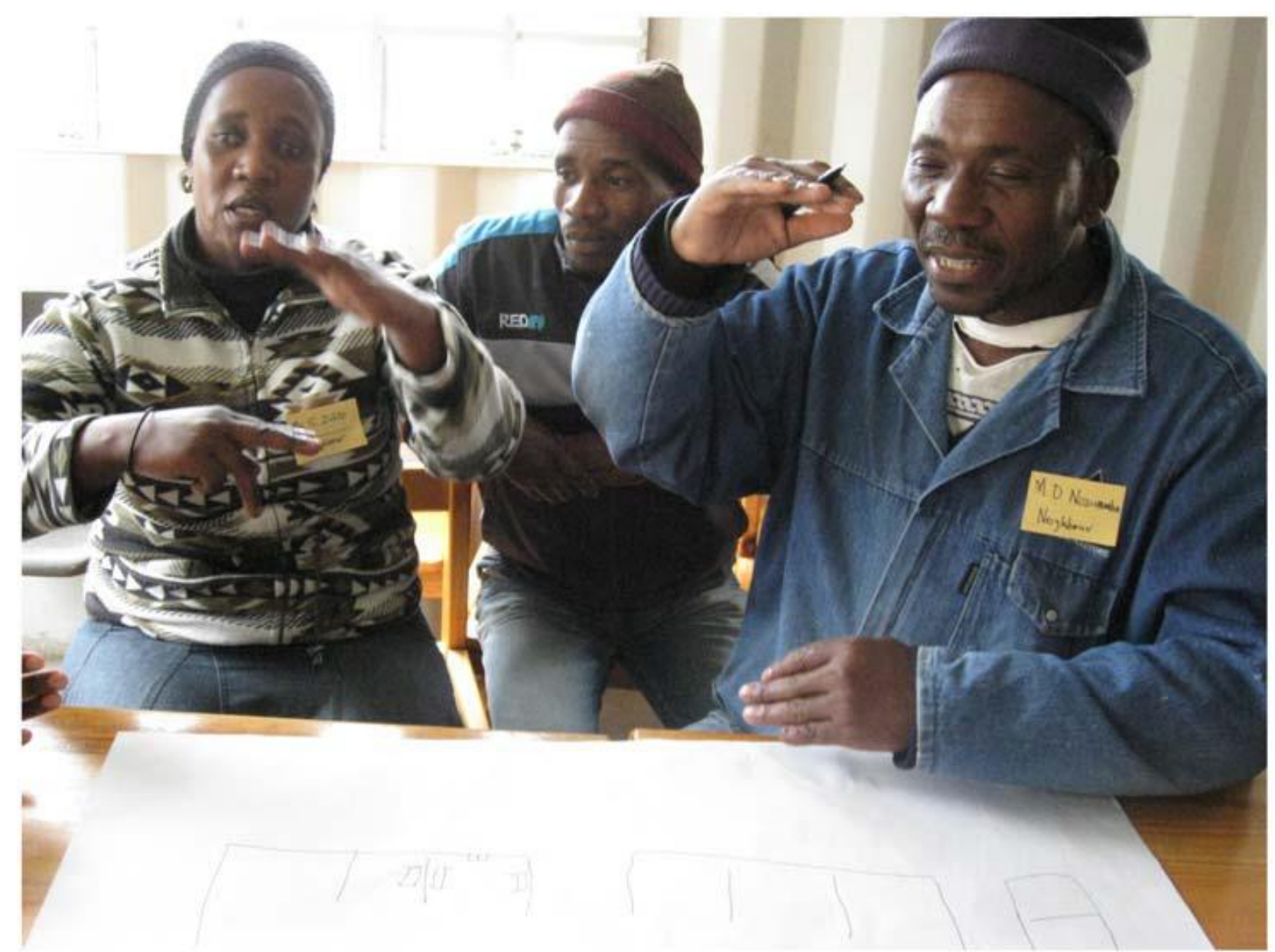

Figure 9. Charette, November 2009. Ms S. Zililo and Mr M.D. Nozihamba, identified as hostel 33 "neighbours" debate details for an envisaged restored Hostel 33. Copyright, Leslie Witz.

The act of de-camping necessarily became an invisible process of ordinariness, of simple housekeeping. Dealing with the dust was a major issue of debate over the representation of cleanliness and dirtiness. Women who had lived in the hostels from the 1980 os showed the museum staff how housekeeping happened. This involved maintaining high standards: these women told of surfaces dusted and wiped, beds immaculately made, clothing ironed, and floors mopped and swept in each demarcated section. Priority was given to personal spaces and possessions in each compartment (Murray 2010). Whether this had happened in the 1960 s in the space of the all-male living quarters, the museum was unable to establish. For the museum, then, the issue was the extent of cleaning for curation. The debate was framed around authenticity, presentation and the museum experience, where depicting and telling the stories of hostel life contained narratives of the effects of overcrowding and human containment. Unable to reach agreement, the museum decided to consult with a specialist conservator, Rayda Becker. Her report both outlined the problem of dirt and suggested limited measures to prevent deterioration of the fabric. Dust, she wrote, was "a two-sided problem": it was "damaging for artefacts," but at the same time "part of the lived reality of the hostel." Her recommendation, which the museum adopted, was: cleaning, but not over-cleaning. 


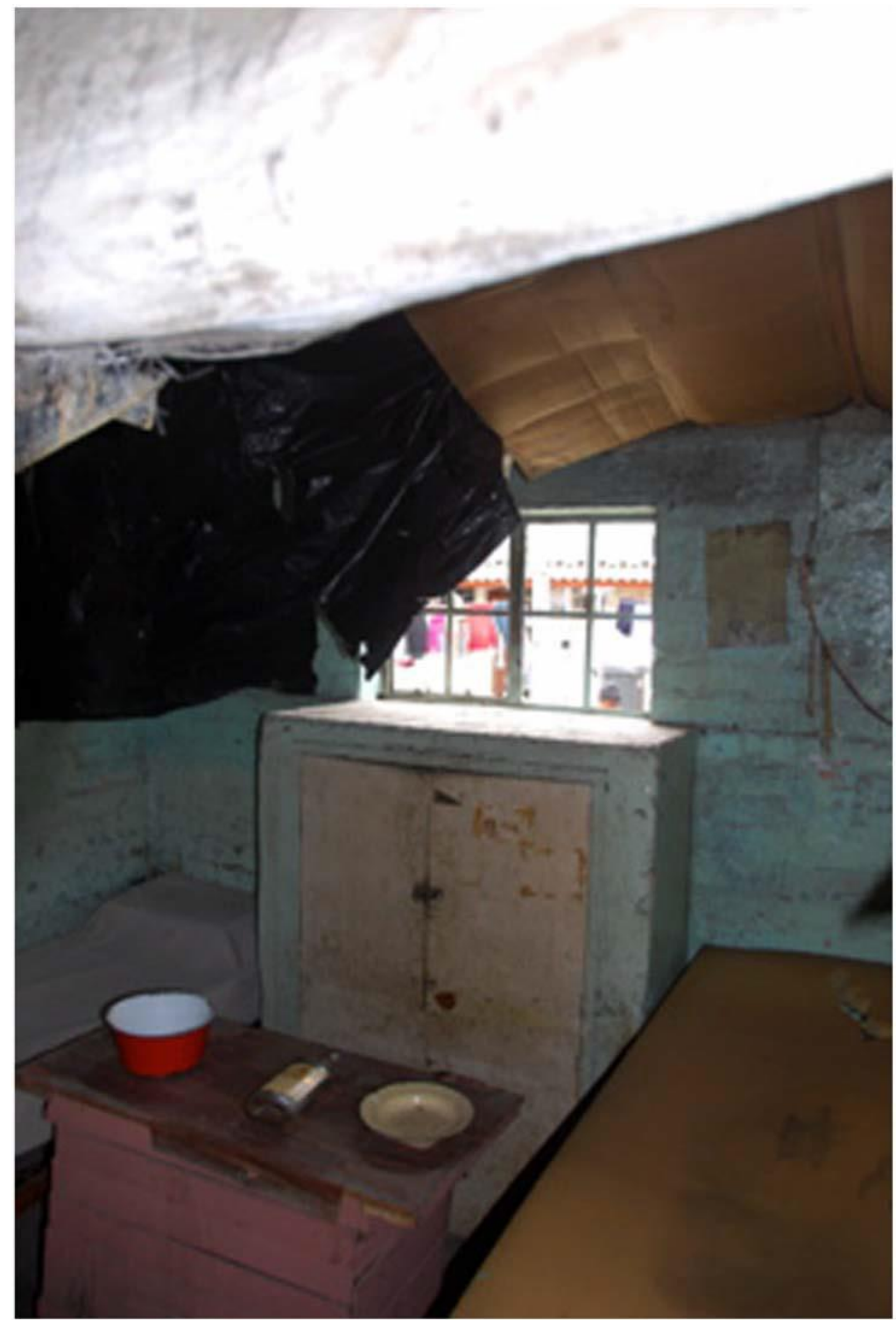

Figure 10. Sagging ceilings, March 2010. Deterioration of makeshift interiors posed questions of removal, replacement or rehabilitation and re-securing of the original material. Copyright, William Martinson.

\section{https://repository.uwc.ac.za/}


(a)

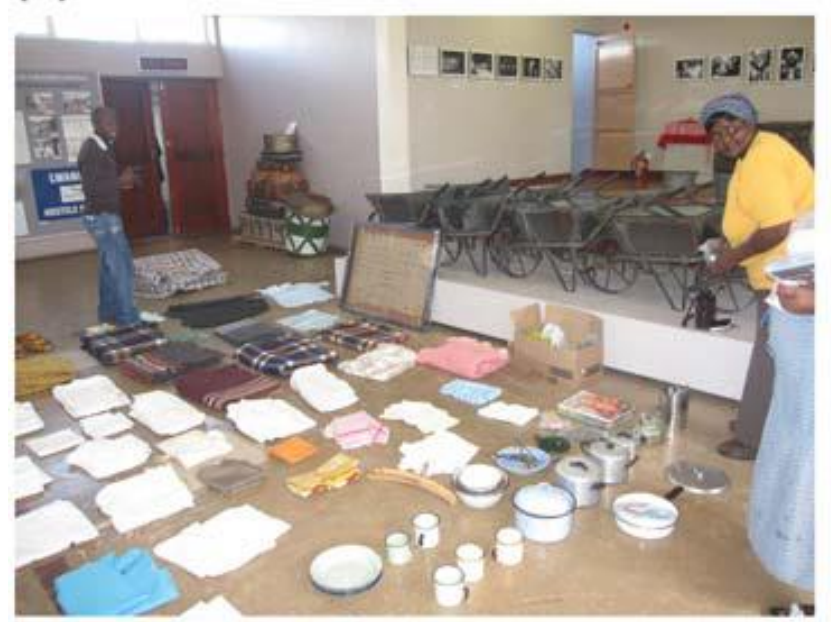

(b)

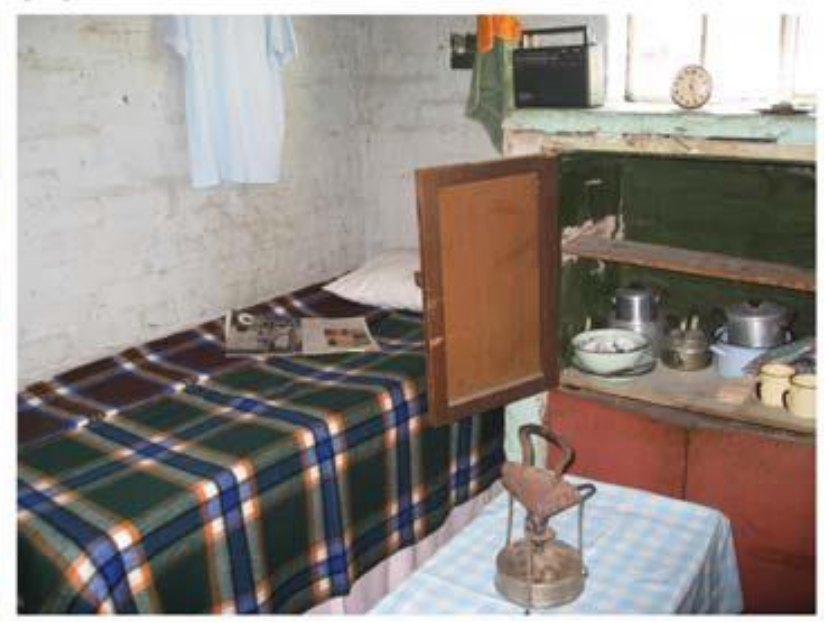

Figure 11. Collecting and displaying, April 2010. Mphumzi Nzuzo, Kholiswa Ncane and Sylvia Monqo prepared, selected and assembled artefacts for dressing the hostel for the museum's tenth birthday. Copyright, Noëleen Murray.

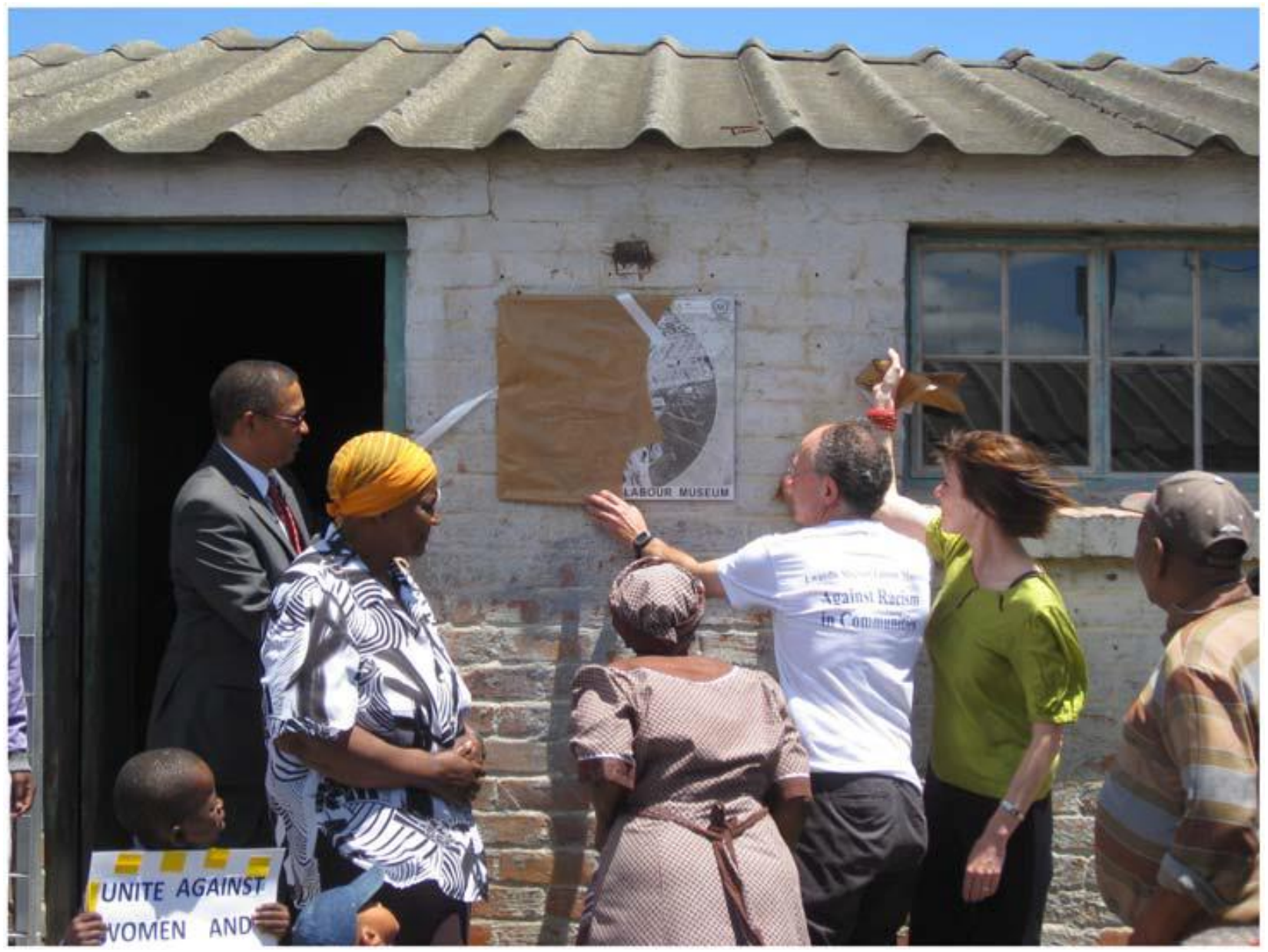

Figure 12. Re-opening Hostel 33 for museum purposes. Ivan Meyer, MEC for Culture and Sport in the Western Cape Province, Mrs Peters, ex-Hostel 33 resident, Leslie Witz, chairperson of Lwandle Museum board and Cynthia Brown from the US Consulate, Cape Town, unveil the restored hostel on December 3, 2011. Copyright, Noëleen Murray 
A low-powered vacuum cleaner was to be "manoeuvred between and around the furniture and over blankets and clothing," and only if necessary was cleaning by hand to be done. The latter would involve using "old rags or washed dust cloths," so that there would be no "loose threads or lint" deposited on the artefacts. In this way, cleanliness could be maintained, the dust removed, and "the curatorial concept of retaining the building and its contents without destroying its complex layered history" could take place. ${ }^{18}$

This general principle of "retaining [...] without destroying" was adopted for stabilising the interior. Instead of removing the informal hessian sacking and cardboard ceilings, the appointed restoration consultant, Paul Grendon, proceeded to reaffix the sagging sections to the roof beams. The timber internal wall partitions between compartments that had further defined the central corridor were stabilized using invisible supports, nails, wedges and staples. "Loose boards," "hanging beams" and exposed protruding nails that were potential hazards for visitors were removed by Grendon.19 Limited electrical fittings were wired and connected, fire protection devices installed, the hostel fumigated and items at risk of disappearing were reproduced. Sourcing appropriate conservation-type materials for these tasks, employing techniques for intervention and finding methods for removal (where appropriate) of dangerous elements might have appeared initially as mundane technical tasks. But this required sensitive interventions and was time-consuming work. Each installation, repair or addition was assessed and approved in terms of an understanding of significance in line with the importance in relation to the age and condition of the building and its meaning in relation to the camp's history. Curating, conserving, cleaning, rehabilitating, restoring and reproducing were the daily tasks of remaking the dilapidated hostel into a museum that envisioned the conditions of the camp.

There were various options open for exhibitionary direction of the various compartments in Hostel 33. There was the possibility of creating a diorama-type display, as had been done at the KwaMuhle Museum in Durban. Then there was the precedent of the Workers' Museum in Newtown, Johannesburg, in which the exhibitionary approach was one of stylisation where film and still images were used to inhabit the compound space along with some artefacts. Another option that was more attuned to the Lwandle museum's direction of creating storied lives is the Lower East Side Tenement Museum's strategy of inhabiting spaces in which the tenement itself is the vehicle to relate stories of life, architecture and interior arrangements. Through dressing spaces and relating narratives, the museum is effectively curated as a tour. The intention in Lwandle was to recreate living spaces in sections of the hostel as part of the visitors' experience. In preparation for the tenth birthday of the museum on May 1, 2010, the museum manager and the education officer, Lunga Smile and Lundi Mama, with members of the museum board, formed part of an exhibition team led by designer Jos Thorne that decided to curate one room intensively as an example of what could be done. Rather than aiming to represent the male migrant hostel of the 1960 s, the idea was to situate this one room in the late 1970 and 1980s. Thorne and stage designer, Vivienne Gray, went out and purchased old beds, blankets or "irugis", magazines, sheets, pots, pans, cutlery, curtains, clothes, overalls, hard hats, trunks, plastic basins, candle sticks and portable radios. These items, identified after studying photographs and in consultation with people who lived in hostels in Lwandle, were specially purchased for exhibition purposes. Visual clues of how to dress 
the rooms, contained in photographs in the museum's archive, those in Jones's book, Assaulting Childhood, and those collected for the Urban Foundation's report on housing in Lwandle in 1988, were supplemented by the knowledge brokers who had lived in the hostel and were enthusiastic to correct the museum's representations of the past. Surfaces of bedholds were dusted, mopped and cleaned out to claim and create a clean living space in an overcrowded, heavily over-used, confined environment. Structures of the beds were elevated using stacked bricks or five-litre empty paint tins so as to ensure that trunks and suitcases could fit below. Beds were made with immaculately ironed sheets and checked rugs, transforming the thin, sparse mattresses and steel beds into sociable, respectable spaces of rest. Crockery and cooking implements were neatly stacked in the single communal cupboard at the centre of each room, providing a display for visitors that sought to replicate the management and arrangement of the bedhold in the cubicle for purposes of sleeping, cooking and eating. A new curtain demarcated boundaries of the compartment, limiting access and signalling an impossible aspiration for privacy. Made up and dressed, the room was ready to go out on show for the birthday party.

The initial idea that had been floated in discussions for the interior of Hostel 33 had been that each room would depict a specific time in the dwelling's history. The experience of dressing one room of the hostel for the birthday party altered this conception. It appeared that what needed to inform the making of the rooms for exhibition were the stories that the museum staff were collecting, the artefacts being assembled by purchase and through exchange with local residents, and the extant fabric of the different rooms. Two rooms were set aside for personal stories of occupation that the museum had collected. Another was emptied out of all furnishings and used to display the state at the time the hostel was vacated in 2007. A third used a remaining cardboard sign indicating the sale of alcohol to recreate a shebeen. A room where, it had been pointed out by Smile, a group of youths had slept in the period since 2000, and which contained a 1999 ANC election poster and cuttings from football magazines, was kept very sparse with two basic beds and blankets as covering. In the final room at one end of the block, two panels were hung showing conditions of living in the hostels and the subsequent developments in the Hostels to Homes scheme. What then became Hostel 33 was not a singular living setting of a specific time period or periods, but rather a space that barely altered the existing fabric, made extensive use of histories of previous inhabitation and was turned into a display environment. The Lwandle Museum had set up home in Hostel 33.

\section{The "new" restored Hostel 33}

The structure and unique interior space of Hostel 33 has now been fully secured by the museum from the condition the building found itself in a few years back when its material presence was deteriorating. At the time of writing, it sits among the homes in the old hostel landscape marked as a museum. Its exhibitions enable the Lwandle Museum to tell tourists, local residents and schoolchildren the stories of those who lived and worked in the migrant labour compound and to elaborate on the conditions experienced over time.

On December 3, 2011, Hostel 33 in Lwandle was opened by the US Consulate's Public Diplomacy Officer, Cynthia Brown, and the Western Cape Minister for Cultural Affairs and Sport, Ivan Meyer. In its public news announcement about the event, the US Consulate in Cape Town noted that where previously "monotonous rows of identical 
whitewashed hostel blocks" had stood "perched on a sand-swept tract of land between the seaside resorts and lush Cape farmland," the Lwandle Migrant Labour Museum had since 2009 peeled back the "layers of history." The event marked the completion of a complex project that had sought to re-make a labour camp of apartheid into a museum artefact. By "painstakingly" restoring the hostel structure to "its original state" of "sagging cardboard ceilings, Sunlight soaplabel wallpaper, makeshift metal bunk beds propped on paint tins, and the hallway 'shebeen'," the museum had made a "new 'Hostel 33' exhibit" (US Diplomatic Mission to South Africa 2011).

At the heart of the project of rehabilitating this migrant labour hostel at the seaside was this constant tension between restoring old and making new. Rather than holding the project back, this tension was productive as ways were experimented with to invoke times past through an extant building. Adjacent structures were pulled down, interiors secured, walls rebuilt, pavements destroyed, broken shards left in place, security apparatus installed, artefacts purchased, old latrines recreated, and the interior and exterior partially cleaned up as the hostel was made into the museum. The Hostels to Homes scheme, in attempting to de-camp the landscape for the future, had provided the foundation for making this new history in Lwandle through the barrack block. The recreation of a shard of the camp (Hostel 33), as a reminder, enabled the old to become new as a sign of the museum and of Lwandle as a place of permanence and settlement. 


\section{Notes}

1. See for example, the Old Fort Prison Complex on Constitution Hill in Johannesburg and the Robben Island Museum.

2. This is a reference to the title of David Goldblatt's book, The Structure of Things Then (1998). A major component of Goldblatt's oeuvre of works concentrated on the spaces of the mines and migrant labour. To this end he became interested in the Lwandle Museum after Bongani Mgijima, the first curator, approached him. This resulted in his generous donation of a copy of his set of photographs entitled The Transported of KwaNdebele for permanent display in the museum.

3. Additional funding for components of the project came from the National Lotteries Board and the National Heritage Council.

4. Application to US Ambassador's Fund for Cultural Preservation, Restoration of Hostel 33, Lwandle Migrant Labour Museum, Cape Town, South Africa, November 27, 2008. This and all archival documents cited hereafter are in the collection of the Lwandle Migrant Labour Museum.

5. Letter from the Divisional Council of Stellenbosch to Provincial Secretary, Native Affairs, December 23, 1955.

6. Urban Areas Commissioner, Cape Western Area to Secretary, Divisional Council of Stellenbosch, October 21, 1954.

7. Secretary Divisional Council of Stellenbosch to C.P.J. van Vuuren, August 22, 1956.

8. Letter from C.P.J. van Vuuren, to the Minister of Native Affairs, H.F. Verwoerd, November

9, 1955; Letter from Divisional Council of Stellenbosch to Provincial Secretary, "Acquisition of land for a Native Location," December 23, 1955. Van Vuuren had originally asked $£ 20,000$ for the farm and then revised it downwards to $£ 18$,ooo before settling on $£ 14$,000.

9. The Divisional Council of Stellenbosch: Layout of Lwandle Native Location Near the Strand, Drawing No. 1189c (revised May '59), Drawn by F.H.S.

10. Board 2, "Ukujonglea phantsi 1977," Lwandle Migrant Labour Museum.

11. Helderberg District Mail, April 11, 1986. All the emphases and italics are in the original.

12. "Spend the night in Lwandle?," Helderberg District Mail, April 25, 1986.

13. "Strand staan vas oor Lwandle teenstand"; "Chamber disputes Strand's view,"

Helderberg District Mail, June 24, 1988.

14. In 1999, this project received the Institute for Housing in South Africa's National Housing Award.

15. Helderberg Municipality Memorandum, 17/18/1, July 1, 1998, RE: Proposed Museum in Lwandle.

16. The reference here is to a sign that the manager of the Lwandle Museum, Lunga Smile placed at the entrance of Hostel 33 in June 2007: "Hostel 33 Lwandle Migrant Labour Museum Purposes ONLY” (N. Murray and L. Witz, Heritage Report for Hostel 33, Lwandle Migrant Labour Museum, 2009).

17. Iimbali zeKhaya (Stories of Home) draws upon interviews and photographs collected by the museum to tell "about the lives of the people of Lwandle and how they have made their homes there. It shows the different meanings that members of the Lwandle attach to the concept of home" (www.lwandle.com).

18. Rayda Becker, Hostel 33 - Lwandle Migrant Labour Museum, Lwandle: Conservation 
Report, July 26, 2011.

19. Becker 2011, Hostel 33 Report.

\section{Notes on contributors}

Leslie Witz is a professor in the History Department at the University of the Western Cape. His major research centres around how different histories are created and represented in the public domain through memorials, museums, festivals and tourism. His book, Apartheid's Festival: Contesting South Africa's National Pasts, was published in 2003 by Indiana University Press. He has also written two books for popular audiences: Write Your Own History (1988) and How to Write Essays (1990). He teaches courses on precolonial African history, museum and heritage studies and public history and tourism. Leslie is the chair of the Board of the Lwandle Migrant Labour Museum and is on the board of the Human Rights Media Centre. He is presently working on a book on changing histories in South African museums.

Noëleen Murray is an architect and academic based at the University of the Western Cape in South Africa. She holds a joint appointment between the Centre for Humanities Research and the Department of Geography and Environmental Studies. Her recent work offers a reading of architecture and urban planning under and after apartheid in which a key conjunction has been between architectural modernism and apartheid modernity. Noëleen is principal editor for the book Desire Lines: Space, Memory and Identity in the Postapartheid City (2007); and co-editor with Premesh Lalu of the 2012 book Becoming UWC: Reflections, Pathways and the Unmaking of Apartheid's Legacy. Noëleen has served on the Board of the Lwandle Migrant Labour Museum since 2001 and is currently working on a book about apartheid and architecture. 


\section{References}

Buthelezi, V. 2005. "The Lwandle Migrant Labour Museum and the South African Jewish Museum: Serving Different Publics in Two Community Museums in the Western Cape." Unpublished MA mini-thesis, University of the Western Cape.

Christopher, A. J. 1994. The Atlas of Apartheid. London: Routledge.

Cooke le Fèvre, Architects and Urban Designers. 2009. "Hostels Upgrade Programme, Nyanga, Langa and Gugulethu." Cooke le Fèvre, Architects and Urban Designers. http://www.claarchitects.co.za/housing.html.

Cooke, J. 2007. "The Form of the Migrant Labour Hostel." Architecture South Africa July/August: 64-69.

Dolkart, A. A. 2007. Biography of a Tenement House in New York City: An Architectural History of 97 Orchard Street. Santa Fe: The Centre for American Places.

Fransen, H., and M. Cook. 1980. The Old Buildings of the Cape. Cape Town: A. A. Balkema.

Frisch, M. 1990. A Shared Authority: Essays on the Craft and Meaning of Oral and Public History. Albany: SUNY Press.

Fullard, M., and N. Rousseau. 2009. "The Farm, the River and the Picnic Spot: Topographies of Terror.” African Studies 68 (3): 351-369.

Goldblatt, D. 1998. The Structure of Things Then. Cape Town: Oxford University Press.

Heap, P. 1977. The Story of the Hottentots Holland. Elandskloof: Peggy Heap.

Humphries, R. 1989. "Administrative Politics and the Coloured Labour Preference Policy during the 1960s." In The Angry Divide, edited by W. James and M. Simons, 169179. Cape Town: David Philip.

Institute for Justice and Reconciliation [IJR] and Lwandle Migrant Labour Museum. 2008. A Community of the Move: Belonging and Migrancy in the Cape. Cape Town: Institute for Justice and Reconciliation.

Jones, S. 1993. Assaulting Childhood. Johannesburg: Wits University Press.

Li/Saltzman Architects, P. C. 2002. Preservation philosophy for 97 Orchard Street, 1 July 2002. Unpublished document provided by the Lower East Side Tenement Museum, New York.

Luke, C. 2011. "US Cultural Heritage Diplomacy in the Balkans and Turkey.” Unpublished mimeo supplied by author, Department of Anthropology, Boston University.

Mabin, A. 1992a. "Comprehensive Segregation: The Origins of the Group Areas Act and its Planning Apparatuses.” Journal of Southern African Studies 18 (2): 405-429.

Mabin, A. 1992b. "Honouring Our Urban Past and Visiting the Future: Notes on the Pilgrims Rest and Kimberley Mine Museums. Unpublished conference paper, University of the Witwatersrand History Workshop: Myths, Monuments, Museums; New Premises? 16-18 July. Wits Institutional Repository Environment on DSpace. http://wiredspace.wits.ac.za/handle/10539/7900.

Martinson, W. and J. Leger. 1992. "The Newtown Compound: Reconstruction or Restoration?" Unpublished Conference paper, University of the Witwatersrand History Workshop: Myths, Monuments, Museums" New Premises?, 16-18 July. Wits Institutional Repository Environment on DSpace. http://wiredspace.wits.ac.za/handle/10539/7895.

Mgijima B. 2010. "Personal Reflections on Museums and the Promise of Transition." August 30. http://bonganimgijima.blogspot.com/2010/08/personal-reflectionson-museums-and.html. 
Mgijima, B., and V. Buthelezi. 2006. "Mapping Museum: Community Relations in Lwandle.” Journal of Southern African Studies 32 (4): 795-806.

Murray, N. 2010. "Restoring Hostel 33." Restoring Hostel 33. March 10. http://hostel33.blogspot.com/2010/03/restoring-hostel-33.html.

Posel, D. 1989. "'Providing for the Legitimate Labour Requirements of Employers': Secondary Industry, Commerce and the State in South Africa during the 1950s and Early 1960s." In Organisation and Economic Change, edited by A. Mabin, 199220. Johannesburg: Ravan Press.

Ramphele, M. 1993. A Bed Called Home. Cape Town: David Philip.

Rapoport, A. 1992. “On Cultural Landscapes." Traditional Dwellings and Settlements Review 3 (2): 33-47.

Shepherd, N., and N. Murray. 2007. “Introduction.” In Desire Lines: Space, Memory and Identity in the Postapartheid City, edited by N. Murray, N. Shepherd, and M. Hall, 1-18. London: Routledge ArchiText Series.

Sloth-Nielsen, J., D. Hanson, and C. Richardson. 1992. Chickens in a Box: A Progressive Participatory Study of Lwandle Hostel Residents' Perceptions of Personal Safety. Pretoria: HSRC.

Thurman, S. 1997. "Umzamo: Improving Hostel Dwellers' Accommodation in South Africa." Environment and Urbanization 9 (2): 43-62.

US Department of State, Bureau of Education and Cultural Affairs. 2012. "Ambassadors Fund for Cultural Preservation." United States Department of State, Bureau of Education and Cultural Affairs. Accessed August 25. http://eca.state.gov/culturalheritage-center/ambassadors-fund-cultural-preservation.

US Department of State, Bureau of Educational and Cultural Affairs, Cultural Heritage Center. 2009. "U. S. Ambassadors Fund for Cultural Preservation Awards." Accessed August 25. http://exchanges.state.gov/media/pdfs/office-of-policy-andevaluations/ambassadorsfund/afcp200glist.pdf.

US Department of State. 2004. The Ambassador's Fund for Cultural Preservation Annual 03/04 Report. http://eca.state.gov/files/bureau/2003-4afcpannual.pdf.

US Diplomatic Mission to South Africa. 2011. "US Mission Supports Lwandle Migrant Labor Museum Restoration Project.” United States Diplomatic Mission to South Africa.

http://southafrica.usembassy.gov/consulcpt news 111203.html.

Urban Design Services. 1987. Lwandle: Investigation into the potential for Black Housing. Cape Town: Urban Foundation.

Williams, P. 2007. Memorial Museums: The Global Rush to Commemorate Atrocities. Oxford: Berg.

Witz, L. 2003. Apartheid's Festival: Contesting South Africa's National Pasts. Bloomington: Indiana University Press.

Witz, L. 2011. "Revisualizing Township Tourism in the Western Cape: The Migrant Labour Museum and the Re-construction of Lwandle." Journal of Contemporary African Studies 29 (4): 371-388.

Witz, L. and N. Murray. 2011. "Writing Museum Biography: Displacing Development and Community in Lwandle." Unpublished paper presented at The Politics of Heritage Conference, University of Michigan / University of the Witwatersrand, Johannesburg, July, 8-9. 